\title{
Prevalence of repetitive strain injuries/work related musculoskeletal disorders in different specialties of dentists
}

\author{
Prevalência de lesões por esforços repetitivos/distúrbios osteomusculares relacionados ao trabalho em \\ diferentes especialidades de cirurgiões-dentistas
}

Ana Giselle Aguiar DIAS'

Cristiam Velozo da SILVA'

Neiandro dos Santos GALVÃO'

\section{ABSTRACT}

Objective

Identify the prevalence of Repetitive Strain Injuries/Work Related Musculoskeletal Disorders in dentists of different specialties from Porto Velho, Rondônia, Brazil.

\begin{abstract}
Methods
A questionnaire about personal and professional informations and the Disabilities of the Arm, Shoulder and Hand Questionnaire, that has questions about movement difficulty, pain symptoms, weakness, stiffness, paresthesia and psychological and sleep impairment related to last week, was given to 200 dentists from Porto Velho city. However, 100 of them gave back the questionnaires appropriately answered within the time limit, consisting of 100 dentists the sample of this study. The collected data was analyzed by simple descriptive statistics and the Spearman nonparametric correlation test was applied between independent variables and the Disabilities of the Arm, Shoulder and Hand Questionnaire disabilities measures, considering $p<0.05$.
\end{abstract}

Results

The questionnaire disability average was "excellent" for the general sample, but it was found statistical correlation between upper disability measurements and two variables: short time in profession (less than ten years) and the Oral and Maxillofacial Surgery, Implantology and Stomatology specialties.

\section{Conclusion}

It is necessary the dentists that are specialists in these areas and the newly graduated ones do a self-assessment and find out if they are neglecting ergonomic standards so they can follow them.

Indexing terms: Cumulative trauma disorders. Dentistry. Human engineering.

\section{RESUMO}

\section{Objetivo}

Identificar a prevalência de lesões por esforços repetitivos/distúrbios osteomusculares relacionados ao trabalho em diferentes especialidades de cirurgiões-dentistas de Porto Velho, Rondônia, Brasil.

\section{Métodos}

Um questionário sobre dados pessoais e profissionais e o questionário Disabilities of the Arm, Shoulder and Hand (Disfunções do braço, ombro e mão), cujas questões abordam dificuldade de movimentação, sintomatologia dolorosa, fraqueza, rigidez, parestesia e comprometimento psicológico e do sono relacionados à semana anterior, foi entregue a 200 cirurgiões-dentistas da cidade de Porto Velho, Rondônia, Brasil, porém, 100 deles devolveram os questionários preenchidos adequadamente e no prazo estabelecido, consistindo em 100 cirurgiões-dentistas a amostra do estudo. Os dados coletados foram analisados através de estatística descritiva simples e o teste de correlação não paramétrico de Spearman foi aplicado entre as variáveis independentes e as medidas de disfunção do questionário Disabilities of the Arm, Shoulder and Hand, considerando-se $p<0,05$.

\section{Resultados}

A média de disfunção do questionário Disabilities of the Arm, Shoulder and Hand se manteve no nível "excelente" ao se analisar a amostra geral. No entanto, as maiores médias de disfunção encontradas mostraram associação estatística com duas variáveis: o menor tempo de graduação (até dez anos) e as especialidades de Çirurgia e traumatologia bucomaxilofacial, Implantodontia e Estomatologia.

\section{Conclusão}

É necessário que os cirurgiões-dentistas especialistas nessas áreas e os recém-formados se autoavaliem e verifiquem se estão negligenciando normas ergonômicas para que então se adéquem a elas.

Termos de indexação: Transtornos traumáticos cumulativos. Odontologia. Engenharia humana.

\footnotetext{
${ }^{1}$ Faculdade São Lucas, Curso de Odontologia. Rua Alexandre Guimarães, 1927, Areal, 78916-450, Porto Velho, RO, Brasil. Correspondência para/ Correspondence
} to: CV SILVA. E-mail: <cristiam_opo@hotmail.com>. 


\section{INTRODUCTION}

The word ergonomics comes from the Greek (ergo=work; normos=norms) andis definedas theadaptation of man to work and vice versa, so it may be possible getting best results in ideal conditions. These conditions are about the prevention of diseases like repetitive strain injuries (RSI) or work related musculoskeletal disorders (WRMD), that are intrinsically associated to equipment choice and the correct ergonomics of professional's work position ${ }^{1-2}$.

The expressions RSI and WRMD refer to musculoskeletal lesions caused by repetitive use or maintenance of inadequate positions, and may be influenced by ergonomic and biomechanical, environmental, psychological, precipitating, occupational and non-occupational factors ${ }^{2}$.

According to scientific literature, there are a lot of occupations that lead to RSI/WRMD, and it has been already proved that the dentist is a one of the risk professionals ${ }^{3}$, due its postural instability during its activities, that must be made inside a few centimeters: the oral cavity. $62 \%$ of general population present musculoskeletal work related pains. Meanwhile, this datum reaches 93\% when the population is formed only by dentists ${ }^{4}$, and this number has been increasing last years ${ }^{5}$.

Literature is still controversial about the most predisposing specialty to cause RSIMRMD. A study that evaluated RSIMRMD prevalence in 100 dentists from Salvador - BA has found as most affected specialty the prosthesis $(11,3 \%)$, followed up by pediatric dentistry $(9,4 \%)$ and periodontics $(7,5 \%)^{6}$.

Another study, however, verified epidemiological status of RSIMRMD in professors from Passo Fundo Dentistry College, in Rio Grande do Sul state, and found the higher numbers of cases in these specialties, in descending order: Oral and Maxillofacial Surgery, Endodontics, Periodontics, Operative Dentistry, Pediatric Dentistry and Prosthodontics ${ }^{7}$.

Another study evaluated muscular behavior of the dentist during dental procedures (Periodontics, surgery and general practice). The result demonstrated Periodontics as the specialty that can most cause muscular fatigue, losing this position only for control group results, formed by non-dentists. Nevertheless, based on the other researched results, the conclusion affirms that, regardless of specialty, dental procedures lead to weariness followed by neck and shoulders muscles fatigue, and may cause occupational diseases; the researchers point only the long time per day of work as a differential factor ${ }^{8}$.
A research involving 140 professionals pointed the Endodontics as the most susceptible specialty to RSIMRMD9. Evaluating the endodontist position during a consultation with or without dental assistant, the professional presented inadequate positions in both situations, demonstrating how difficult is keeping ergonomics in this specialty, even there is a dental assistant ${ }^{10}$

A research made in Thessaloniki, Greece tried to evaluate musculoskeletal disorders in dentists and compared general dentists with orthodontists. The 12-month prevalence of pain on hand/wrist differed significantly between orthodontists and general dentists: this prevalence reached $42,1 \%$ for orthodontists, and $25,5 \%$ for general dentists. However, about shoulder pain, general dentists presented a prevalence of $21,2 \%$, where $0 \%$ was observed for orthodontists. Hand/wrist pain is responsible for more than $50 \%$ of total absences of orthodontists ${ }^{11}$

Pediatric Dentistry is a specialty that presumptively may cause RSI/WRMD, because children treatment often leads the dentist be in an inadequate position to execute a certain procedure, according to the child behavior. But a study evaluated 360 procedures made by 8 th-period graduation students at Pediatric Dentistry Clinic and the results did not demonstrated correlation between child behavior/kind of procedure and the work position of dentist. The conclusion affirms that the inadequate work postures are not because of the difficulties of treating children, but because of postural habits acquired by the students during clinical activities ${ }^{12}$.

Therefore, it is observed a great divergence between the results of studies about RSI/WRMD in dentists, especially about which specialty is the most susceptible. This research tried to be a contribution to the study of this problem, searching for data about RSIMRMD situation in dentists of different specialties from Porto Velho (RO), once there is not literature about this subject in the region. So, the aim of this study was identify the prevalence of Repetitive Strain Injuries/Work Related Musculoskeletal Disorders in dentists of different specialties from Porto Velho, Rondônia, Brazil.

\section{METHODS}

Before starting this research, its project was submitted to the Research Ethics Committee of São Lucas College with the process number 773/2010, and was considered suitable to be executed. 
This is a cross-sectional observational study in which we used the DASH questionnaire validated for the Portuguese language, consisting of one module of 30 questions about disability/symptoms and two optional modules with 4 items to be answered in each module (one that analyzes sporting and musical activities and other that analyzes work activities ${ }^{13}$. In this study, the optional module related to sports and the use of musical instruments was not used, because it is not compatible with the purpose of the study, which evaluates RSI/WRMD in the professional scope.

The questions are about difficulty moving, painful symptoms, weakness, stiffness, numbness and psychological and sleep impairment related to the previous week; each question presents 5 answer choices with different scores and the total score ranges from 0 (no disability) to 100 (severe disability) for each module.

The scores obtained in each module, ranging from 0 to 100 , quantify the degree of disability of the upper limbs, and may be classified as: Excellent: $<20$ points; Good: 20-39 points; Regular: 40 to 60 points; Bad: $>60$ points ${ }^{14}$.

To define the sample to be studied, we requested the Dentistry Regional Council of Rondonia a list of dentists in Porto Velho (RO), with their respective work addresses. Issued on 08/31/2010, this list had 523 professionals and over this value, a formula to estimates of proportion was applied in order to determine the study sample ${ }^{15}$.

Thus, with a population of dentists equal to 523, we obtained an estimated sample around 222 dentists ( $42 \%$ of the population) that were divided according to areas of the city (North, South, East and West) corresponding to their addresses. Therefore, the research sample becomes in clusters, with two levels (individual and city region), being necessary to bend it. Then, after rounding, the sample was set to 440 dentists proportionally distributed in the four geographical areas of Porto Velho (RO).

The dentists selected for the sample would be found in their work addresses, informed about the study objectives and asked to participate in it, by signing the term of free and informed consent and answering the DASH questionnaire and a form with personal and professional data, with a deadline of a week to fill these documents.

At the start of the data collection, it was observed that many of the addresses of the dentists' list provided by the Dentistry Regional Council of Rondonia were residential, constituting a halt to the research, since the professional approach in his home would invade his privacy. And, since we considered only professional addresses, many dentists do not entered the sample, because they do not exercise the profession anymore, having no work address. Another difficulty was the refusal of many professionals to participate in the research.

Thus, the sample of 440 dentists was not achieved. 200 professionals initially agreed to participate in the study signing the term of free and informed consent and had a week to answer the questionnaires; 138 dentists returned the questionnaires on time. Of this total, 100 questionnaires were properly filled, consisting of 100 professionals our sample $(22.7 \%$ of the sample of 440 professionals, defined previously).

The variables evaluated were those proposed by the DASH questionnaire modules, as well as those contained in the form of personal and professional data, which consisted of date of birth, gender, year of graduation, specialty (s), how long specialized, amount of assistants in the office and quantity of the daily working hours.

The collected data was analyzed by simple descriptive statistics and presented through Figures and Tables; the Spearman nonparametric correlation test was applied between independent variables and the DASH questionnaire disabilities measures, considering $p<0.05$.

Exclusion criteria of the elements from the sample were based on the non-fulfillment or improper fulfillment of any of the documents delivered to the dentists.

\section{RESULTS}

Regarding gender of respondents, 40 (40\%) were men and 60 (60\%) women. With regard to age, 48 (48\%) dentists were between 21 and 30 years old, 32 (32\%) were between 31 and 40, 10 (10\%) were between 41 and 50 and other 10 (10\%) between 51 and 60 .

Most of the dentists (66\%) graduated between 2001 and 2010; 22\% graduated between 1991 and 2000; 9\% between 1981 and 1990 and only 3\% graduated between 1971 and 1980 .

$72 \%$ of the dentists have at least one assistant and the remaining $28 \%$ work without assistants in the office. The daily working hours is 8 hours for more than half of the analyzed professionals (54\%). The rest of the professionals have daily working hours ranging from 3 to 14 hours.

Little more than half of the dentists evaluated (54\%) are general dentists. Specialists constitute $46 \%$ of the sample, with 6 professionals with two specialties (Table 1). 
Table 1. Amount of general and specialists dentists of the analyzed sample.

\begin{tabular}{lc}
\hline Specialties & $\%$ \\
\hline General Clinic & $54 \%$ \\
Oral and Maxillofacial Surgery & $1 \%$ \\
Operative Dentistry & $2 \%$ \\
Endodontics & $7 \%$ \\
Stomatology & $1 \%$ \\
Implantology & $5 \%$ \\
Forensic Dentistry & $1 \%$ \\
Pediatric Dentistry & $1 \%$ \\
Orthodontics & $9 \%$ \\
Periodontics & $3 \%$ \\
Prosthodontics & $9 \%$ \\
Public Oral Health & $1 \%$ \\
Operative Dentistry and Prosthodontics & $1 \%$ \\
Operative Dentistry and Pediatric Dentistry & $1 \%$ \\
Operative Dentistry and Labor Dentistry & $1 \%$ \\
Operative Dentistry and Public Oral Health & $1 \%$ \\
Forensic Dentistry and Labor Dentistry & $1 \%$ \\
Geriatric Dentistry and Labor Dentistry & $1 \%$ \\
\hline
\end{tabular}

From the analysis of the variables proposed by the DASH questionnaire, it was found that $83 \%$ of the dentists reported not to be limited at work or perform daily activities due to problem in the arm, shoulder or hand; $78 \%$ have no difficulty using their usual technique work or to do their work as well as they would like; and $76 \%$ do their usual work without difficulty or changes in the amount of time spent at work.

However, $44 \%$ reported having difficulty carrying a heavy object (over 5 kilos), 48\% reported pain in the arm, shoulder or hand pain and $45 \%$ feel pain in these locations when performing any specific activity. Tingling $(23 \%)$, weakness (30\%) and stiffness (18\%) in the arm, shoulder or hand were also observed in the dentists.

The averages of scores of the sample are classified as excellent: 9 in Disability/Symptoms Module and 8 in Performance at Work Module, with a standard deviation of 9.5 and 14.7, respectively. Regarding the scores of the Disability/Symptoms Module, $89 \%$ of the sample had scores in the "excellent" level, and 15\% presented values equal to $0 ; 9 \%$ had values in the "good" level; the "regular" and "bad" levels were represented for $1 \%$ each. The Performance at Work Module identified $85 \%$ of dentists in the "excellent" level (65\% with values equal to $0) ; 11 \%$ of professionals were in the "good" level; $2 \%$ in the "regular" level and $2 \%$ in "bad" level.
To analyze the scores according to the time of graduation, the dentists were grouped into two ranges: graduated between 2001 and 2010 (less than ten years) and graduated between 1971 and 2000 (more than ten years). The average of scores of Disability/Symptoms Module was 9 for both groups and of Performance at Work Module was 7 for graduated for more than ten years and 8 for graduated for less than ten years.

Comparing the scores of general dentists to specialists (regardless of specialty), we obtained the results shown in Figure 1, where we can note that the highest averages are of specialists.

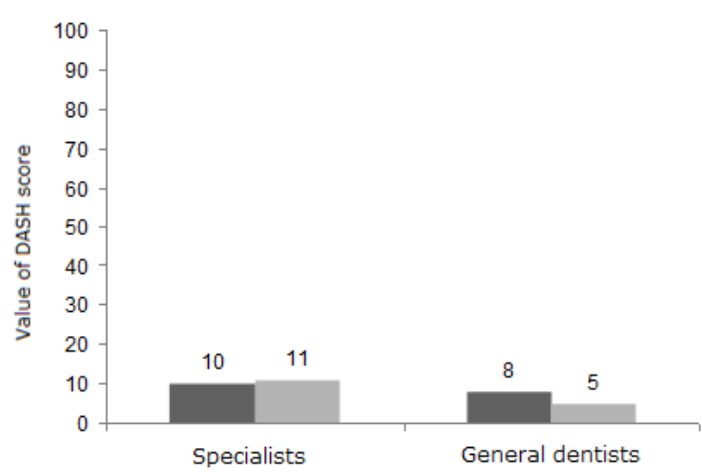

= Score of Disability/Symptoms Module = Score of Performance at Work Module

Figure 1. Averages of DASH scores of the general dentists and specialists analyzed.

In the analysis of the specialties, these were grouped by similar aspects they have; this way, Operative Dentistry and Prosthodontics are the group 1, involving in their skills greater use of high speed handpieces to prepare cavities for direct and indirect restorations; Oral and Maxillofacial Surgery, Implantology and Stomatology form the group 2 due to the practice of surgeries that these specialties have in common; Endodontics and Periodontics stand by meticulous movements and fine sensibility, forming the group 3; Group 4, formed by Public Oral Health, Forensic Dentistry and Labor Dentistry, was based on the highest acting in administrative activities and public health; Group 5 consisted of specialties dealing with the extremes of age and its inherent complications: Pediatric Dentistry, Orthodontics and Geriatric Dentistry; Finally, the group 6 includes all general dentists.

So the evaluated scores of the questionnaire DASH modules of each group are shown in Figure 2, showing that, surprisingly, the Group 4 showed high levels of scores when compared to the levels of most of the other groups; it was also found that in this group is the professional with the highest score in Disability/Symptoms Module (51.7) 
and the second highest score of the Performance at Work Module (62.5). It is also important to note that this group had $50 \%$ of reports of mild and strong pain in the arm, shoulder or hand and two thirds had mild, medium or strong pain when performing specific activities.

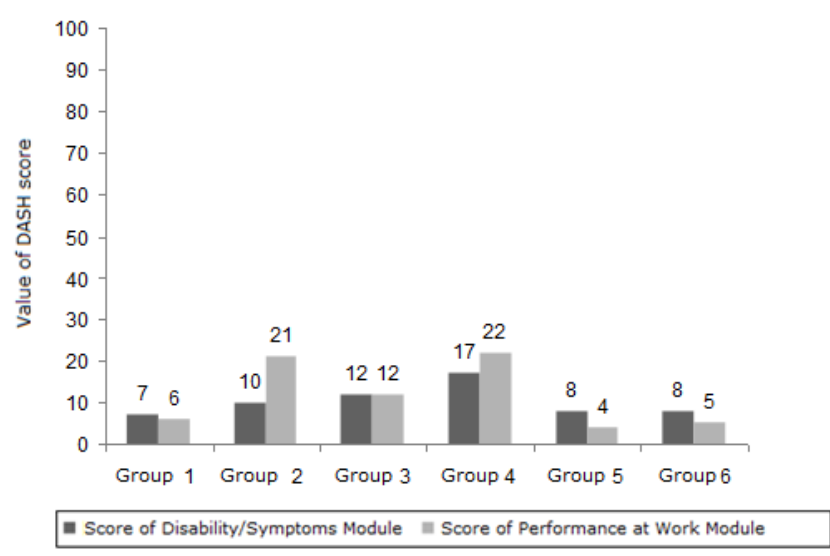

Figure 2. Averages of DASH scores of the specialties groups of the dentists analyzed.

About the time of working as a specialist, we compared the scores between professionals that are specialists for less than tem years and the ones that are specialists for more than ten years, and the same was made with the general dentists that have been working for less than ten years and the ones that have been working for more than ten years. Data were expressed in Figure 3. It was possible to observe that specialists with less than ten years of specialized showed higher scores averages than specialists with more than ten years of practice of the specialty. The same situation was observed for general dentists, where graduated for less than ten years had higher scores than graduated for more than ten years.

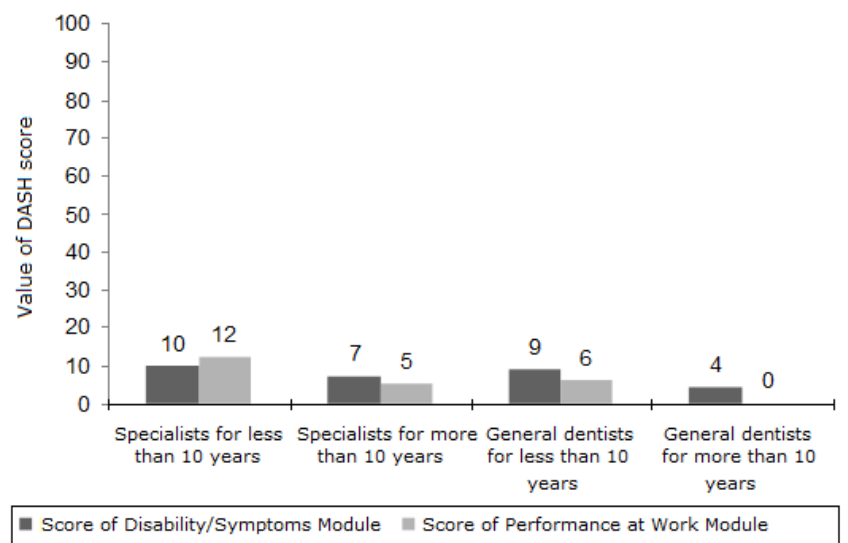

Figura 3. Averages of DASH scores according to the time of work in this profession of the specialists and general dentists analyzed.
Regarding the Spearman correlation test (Table 2) between the variables and the values of DASH, statistical correlation was observed only in the variable year of graduation ( $p=0.0052$ ), evidencing that the graduated for less than ten years showed higher disability than the graduated for more than ten years, even specialists or not. Applying this same test in the groups of specialties, only group 2 (Oral and Maxillofacial Surgery, Implantology and Stomatology) showed statistical correlation ( $p=0.0336)$ with the values of DASH. Both correlations were found in the values of the Performance at Work Module of DASH.

Table 2. Spearman correlation coefficients between the values of DASH scores and the analyzed variables (considering $\mathrm{p}<0.05$ ).

\begin{tabular}{|c|c|c|c|c|}
\hline \multirow[b]{2}{*}{ Variables } & \multicolumn{2}{|c|}{$\begin{array}{l}\text { Disability/ } \\
\text { Symptoms } \\
\text { Module }\end{array}$} & \multicolumn{2}{|c|}{$\begin{array}{l}\text { Performance at } \\
\text { Work Module }\end{array}$} \\
\hline & $r_{s}$ & $\begin{array}{l}\text { Value } \\
\text { of } p\end{array}$ & $r_{s}$ & $\begin{array}{l}\text { Value } \\
\text { of } p\end{array}$ \\
\hline Gender & $-0,1054$ & 0,4228 & 0,0378 & 0,7743 \\
\hline Age & 0,2384 & 0,0887 & 0,2403 & 0,0861 \\
\hline Year of graduation & 0,214 & 0,0844 & 0,3402 & 0,0052 \\
\hline Daily working hours & 0,0362 & 0,7949 & $-0,0424$ & 0,761 \\
\hline $\begin{array}{l}\text { Presence or not of } \\
\text { assistant }\end{array}$ & 0,1333 & 0,2641 & $-0,1448$ & 0,2249 \\
\hline Being specialist or not & 0,0895 & 0,5197 & 0,1535 & 0,2677 \\
\hline $\begin{array}{l}\text { Being general dentist for } \\
\text { more or less than } \\
10 \text { years }\end{array}$ & 0,2487 & 0,0848 & - & - \\
\hline $\begin{array}{l}\text { Being specialist for more } \\
\text { or less than } 10 \text { years }\end{array}$ & $-0,006$ & 0,9705 & $-0,2333$ & 0,1473 \\
\hline Group 1 & 0,0539 & 0,6242 & 0,0859 & 0,4344 \\
\hline Group 2 & 0,1462 & 0,1619 & 0,2204 & 0,0336 \\
\hline Group 3 & 0,09 & 0,3988 & $-0,0469$ & 0,6608 \\
\hline Group 4 & 0,1611 & 0,1208 & 0,1474 & 0,1561 \\
\hline Group 5 & $-0,0342$ & 0,752 & $-0,0408$ & 0,7056 \\
\hline
\end{tabular}

\section{DISCUSSION}

The difficult diagnosis of RSIMRMD, due to the complexity of factors involved in this type of disease, becomes occupational diseases a controversial issue among experts ${ }^{7}$. Thus, this study presented data in agreement and in disagreement with the literature.

The sample, which was estimated to be 440 professionals, was based on 100 (22.7\% of the estimated sample). In a study of Regis Filho et al. ${ }^{3}$ evaluating RSI/ WRMD among dentists, questionnaires were sent to 3618 professionals by letter and reply card conventional system. Of this number, 523 were returned due to change of address and 771 returned properly filled out, ie $24.91 \%$ of the valid 
questionnaires. Even though not a scientific argument, but claiming to be the only one in the literature, the author was justified in the Brazilian Post and Telegraph, which says that, due to the experience of decades offering this type of service, in this type of research is not expect a higher return than 10\%; thus, the authors considered, though comparatively, the percentage of questionnaires excelente ${ }^{3}$. Thus, as in the present study we used a similar methodology, in which the questionnaires were delivered to dentists and asked to respond in a particular period, reaching $22.7 \%$ of the sample can be considered satisfactory.

The profile of the studied population is mostly female $(60 \%)$, young ( $80 \%$ aged 40 or less), recently graduated (66\% graduated in the last 10 years), which works with at least one auxiliary the office (72\%) for 8 hours a day (54\%) and is not specialized (54\% are general dentists).

Regarding pain symptoms, nearly half of professionals (48\%) reported pain in the arm, shoulder or hand, while $45 \%$ feel such pains when performing specific activities. This result is similar to the study of Santos Filho \& Barreto $^{16}$, who found a percentage of $58 \%$ of dentists with complaints of musculoskeletal pains in one or more regions of the upper body. Regis Filho et al. ${ }^{3}$ obtained a percentage of $56.68 \%$ of these professionals with painful symptoms in the upper limbs, shoulder or neck. Gazzola et al. ${ }^{17}$, in turn, had a finding of $98.6 \%$ of dentists with musculoskeletal pains, a result very similar to Cunha et al. ${ }^{18}$ who, in their study evaluating professionals from the Family Health Program Center in Campina Grande (PB), found $100 \%$ of the professionals analyzed in pain.

Although results of musculoskeletal pain have been found, the averages of scores of the DASH questionnaire remained in the "excellent" level, ie, respondents showed no impairment of the upper limbs, thus constituting a new find in the literature.

This result can be explained by the young profile of the studied population and their short time of exercise of the profession. Abreu et al. ${ }^{19}$ investigated RSIMRMD in dentistry undergraduates and found no disturbances in these students, justifying the students' profile, which was a hegemonic youth group, reporting adequate sleep and having no work activities off course. However, this hypothesis favoring youth disagrees with the study by Gazzola et al. ${ }^{17}$ where younger professionals (under 40 years) had neck pain more frequently than those who were more than 40 years old; and the study of Garbin et al. ${ }^{4}$, where it was observed that the age group 35-39 years old was the most affected by painful symptoms.
Regarding time of work in this profession, the Spearman correlation test accused that most of disability observed in professionals graduated for less than 10 years compared to graduated ones for more than 10 years has statistical significance $(p=0.0052)$. In agreement with this statement, Garbin et al. ${ }^{4}$ found a considerable number of professionals $(17.41 \%)$ with pains graduated for less than five years. However, Regis Filho et al. ${ }^{3}$ found that dentists with more than 20 years of profession had a higher number of cases with more than five years of pain than those who had up to 10 or even 20 years of professional practice.

Ruh et al. ${ }^{20}$ evaluating photos of the service performed by Dentistry students, found adopting postures and behaviors that may lead to the development of carpal tunnel syndrome over the years of professional experience. Michelin et al. ${ }^{7}$ affirmed that dentists are prone to acquire RSIMRMD regardless of time of practice, unless it follows the rules of ergonomics, with equipment and postures to improve your work performance and physical wellbeing. Thus, failure to follow the ergonomic standards by these professionals graduated less than ten years there may be a reason for the result of this study.

As regards the specialty the professionals were divided into groups. All averages of DASH scores of all groups remained in the "excellent" level, with the exception of the groups 2 (Oral and Maxillofacial Surgery, Implantology and Stomatology) and 4 (Public Oral Health, Forensic Dentistry and Labor Dentistry), which showed the average of Performance at Work Module in the "good" level.

The lowest averages were in group 1 (Operative Dentistry and Prosthodontics). This result is similar to that found by Michelin et al. ${ }^{7}$. However, Garbin et al. ${ }^{4}$ found the highest percentage of painful symptomatology in specialists in Operative Dentistry.

Group 5 (Pediatric Dentistry, Orthodontics and Geriatric Dentistry) and group 6 (general dentists) are following group 1, with very similar averages. General dentists demonstrate their privileged position with its percentage of professionals who do not feel pain in the arm, shoulder or hand: $53.7 \%$. Of the $46.3 \%$ who claim to feel pain, more than two thirds $(72 \%)$ classified their pain as mild. In favor of Pediatric Dentistry, it has been proven that its supposed predisposition to RSIMRMD because of the difficulties of child care does not exist ${ }^{12}$.

Alexopoulos et al. ${ }^{11}$ in turn, found discrepancies between data on orthodontists and general dentists, observing a higher prevalence of pain in the hand/wrist in orthodontists; however regarding shoulder pain, general dentists had higher prevalence than orthodontists. 
Group 3 (Endodontics and Periodontics) appears here in an intermediate position, being the only group to have equal averages (12) in the two modules. The literature, however, in contrast to this study, puts most often these specialties at extreme positions.

Lopes et al. ${ }^{9}$ argued that Endodontics is the specialty more susceptible to RSIMRMD. Gazzola et al. ${ }^{17}$ found an association between Endodontics and musculoskeletal disorders in the shoulders, forearms and lower back. They also state that the maintenance of postures that this specialty requires leads, along time, to shoulder fatigue, which is the joint that serves as support for the meticulous moves that hand performs.

In contrast, Garbin et al. ${ }^{4}$ found lower rates of painful symptoms among specialists in endodontics. Michelin et al. ${ }^{7}$ put Endodontics and Periodontics as the specialties with the highest number of confirmed cases of disorders, second only to Oral and Maxillofacial Surgery.

Periodontics is also observed as the specialty that showed the highest level of muscle fatigue in the study of Casarin \& Caria ${ }^{8}$. Santana et al. ${ }^{6}$ in turn found lower rates of complaints of RSIMRMD in specialists in Periodontics.

Following, group 2 (Oral and Maxillofacial Surgery, Stomatology and Implantology), is the second group with the highest average DASH disability, and the professional with the highest average in Performance at Work Module is in this group. Moreover, a high percentage (57.1\%) reported feeling pain in arm, shoulder or hand, not only of mild character, but also medium character.

Corroborating these results, Michelin et al. ${ }^{7}$ reported the Oral and Maxillofacial Surgery as a specialty with the highest prevalence of disorders. Gazzola et al. ${ }^{17}$ found associations between musculoskeletal disorders in the elbows with this specialty. On the other hand, Casarin \& Caria $^{8}$ demonstrated that surgery procedures are the ones with the lowest rate of muscle fatigue.

Heading the list as the group with the highest disability average is the group 4 (Public Oral Health, Forensic Dentistry and Labor Dentistry), that belongs to the professional with the highest score in Disability/Symptoms Module and the professional with the second highest score in Performance at Work Module.

This result was unexpected, because supposedly professionals of these specialties do not have much daily time of clinical practice. However, $50 \%$ of these professionals had pain in the arm, shoulder or hand, mild and strong character; and two thirds of these specialists say feeling pain in these places of mild, medium or strong character when performing specific activities.
The surprise of the result is evidenced in the literature, which is scarce in similar results. Only Gazzola et al. ${ }^{17}$ found a significant association between Public Oral Health and musculoskeletal disorders of the forearm.

However, the Spearman correlation test between groups of specialties and the measures of DASH disability only presented statistical significance $(p=0.0336)$ for group 2 (Oral and Maxillofacial Surgery, Stomatology and Implantology).

\section{CONCLUSION}

Based on the data presented and analyzed in this study referring to the group studied, it is seen that the population profile of dentists from Porto Velho (RO) is a young, professionals graduated for less than ten years, without specialty, working 40 hours per week, with an assistant in the office.

The DASH averages of the sample analyzed showed no levels accusing disability in the arm, shoulder or hand; probably disability levels were not found in the professionals because these professionals have no predisposing factors for RSI/WRMD; however, the year of graduation appear to influence the levels of disability checked by DASH, being graduated for less than ten years more affected than graduated for more than ten years; this could be explained by the neglect of ergonomic factors by these newly graduated professionals.

Although the highest averages of disability indicated by the DASH have been of group 4 (Public Oral Health, Forensic Dentistry and Labor Dentistry), only the averages of group 2 (Oral and Maxillofacial Surgery, Stomatology and Implantology) were statistically relevant.

There needs to be a self-assessment by the newly graduated professionals and specialists in Oral and Maxillofacial Surgery, Stomatology and Implantology regarding following ergonomic standards and the use of equipment that comply with these principles in order to ascertain if there is neglect of these factors and to adapt themselves to them.

\section{Collaborators}

AGA DIAS supervised the research and participated in the statistical analysis and writing of the article. CV Silva was responsible for collecting and analyzing data and writing the article. NS GALVÃO participated in the data collection and writing of the article. 


\section{REFERENCES}

1. Garbin AJl, Garbin CAS, Ferreira NF, Saliba MTA. Ergonomia e o cirurgião-dentista: uma avaliação do atendimento clínico usando análise de filmagem. Rev Odonto Ciênc 2008;23(2):130-3.

2. Sakata RK. Lesão por esforços repetitivos: doença osteomuscular relacionada ao trabalho (DORT). Rev Bras Med. 2001;58(4):210-6.

3. Regis Filho GI, Michels G, Sell I. Lesões por esforços repetitivos/ distúrbios osteomusculares relacionados ao trabalho em cirurgiões-dentistas. Rev Bras Epidemiol. 2006;9(3):346-59. doi: 10.1590/S1415-790X2006000300009.

4. Garbin AJl, Garbin CAS, Diniz DG. Normas e diretrizes ergonômicas em odontologia: o caminho para a adoção de uma postura de trabalho saudável. Rev Odontol Univ Cid São Paulo. 2009;21(2):155-61.

5. Medeiros UV, Segatto GG. Lesões por esforços repetitivos (LER) e distúrbios osteomusculares (Dort) em dentistas. Rev Bras Odontol 2012;69(1):49-54.

6. Santana EJB, Rocha LEFL, Calmon TRV, Alves IL. Estudo epidemiológico de lesões por esforços repetitivos em cirurgiõesdentistas em Salvador - BA. Rev Fac Odontol Univ Fed Bahia. 1998;17(1):67-74.

7. Michelin CF, Michelin AF, Loureiro CA. Estudo epidemiológico dos distúrbios musculoesqueletais e ergonômicos em cirurgiõesdentistas. RFO UPF. 2000;5(2):61-7.

8. Casarin CAS, Caria PHF. Comportamento muscular durante diferentes práticas odontológicas. Cienc Odontol Bras. 2008;11(2):64-70.

9. Lopes FF, Pereira FTF, Cutrim MCFN, Oliveira AEF, Alves CMC. Prevalência dos distúrbios osteomusculares relacionados ao trabalho em cirurgiões-dentistas de São Luís - MA. In: 20a Reunião Anual da SBPqO; 2003; Águas de Lindóia. Anais. Águas de Lindóia: Sociedade Brasileira de Pesquisa Odontológica; 2003. p. 227.

10. Michelotto AL, Silva Junior JA, Sydney GB. Uma abordagem ergonômica postural durante o tratamento endodôntico. JBC J Bras Clin Odontol Integr. 2005;9(50/51):192-8.

11. Alexopoulos EC, Stathi IC, Charizani F. Prevalence of musculoskeletal disorders in dentists. BMC Musculoskelet Disord. 2004;5:16.
12. Garcia PPNS, Campos JADB, Zuanon ACC. Avaliação clínica das posturas de trabalho empregadas na clínica de odontopediatria por estudantes de odontologia. Pesqui Bras Odontopediatria Clin Integr. 2008;8(1):31-7.

13. Orfale AG, Araújo PMP, Ferraz MB, Natour J. Translation into brazilian portuguese, cultural adaptation and evaluation of the reliability of the disabilities of the arm, shoulder and hand questionnaire. Braz J Med Biol Res. 2005;38(2):293-302. doi: 10.1590/S0100-879X2005000200018.

14. Hudak PL, Amadio PC, Bombardier C. Development of an upper extremity outcome measure. The DASH (Disabilities of the Arm, Shoulder and Hand). Am J Ind Med. 1996;29(6):602-8.

15. Levine DM, Berenson ML, Stephan D, Krehbiel TC. Estatística: teoria e aplicações. $5^{a}$ ed. Rio de Janeiro: LTC; 2008.

16. Santos Filho SB, Barreto SM. Atividade ocupacional e prevalência de dor osteomuscular em cirurgiões-dentistas de Belo Horizonte, Minas Gerais, Brasil: contribuição ao debate sobre os distúrbios osteomusculares relacionados ao trabalho. Cad Saúde Pública. 2001;17(1):181-93. doi: 10.1590/S0102$311 \times 2001000100019$.

17. Gazzola F, Sartor N, Ávila SN. Prevalência de desordens musculoesqueléticas em odontologistas de Caxias do Sul. Rev Ciênc Saúde. 2008;1(2):50-6.

18. Cunha CC, Marques BD, Farias SCSA. Sintomatologia da síndrome do desfiladeiro torácico em cirurgiões dentistas. Tema - Rev Eletr Ciências. 2011;12(17):1-9.

19. Abreu MHNG, Costa AR, Braga AR, Moraes GFS. DASH entre estudantes de curso de odontologia, Belo Horizonte, 2007. Rev ABENO. 2008;8(1):16-22.

20. Ruh AC, Teider DJ, Schleder SR. Análise de condutas e posturas dos acadêmicos de odontologia com predisposição à síndrome do túnel do carpo. Publ UEPG Cienc Biol Saúde. 2011;17(1):59-71. 